\title{
Groundwater quality degradation of urban areas (case study: Tehran city, Iran)
}

\author{
T. Nasrabadi $\cdot$ P. Abbasi Maedeh
}

Received: 30 October 2012/Revised: 27 April 2013/Accepted: 17 May 2013/Published online: 26 June 2013

(C) Islamic Azad University (IAU) 2013

\begin{abstract}
Groundwater quality of Tehran city is considered in this study. Nine sampling stations were selected, and composite sampling campaign was performed in summer 2012. Groundwater sampled from northern stations appeared to have acceptable characteristics for agricultural and drinking uses. The southern station samples did not meet the required guidelines. Concentration of $\mathrm{SO}_{4}{ }^{2-}, \mathrm{Na}^{+}$and $\mathrm{Cl}^{-}$obey a sharp ascending trend southwards. Accordingly, the electrical conductivity of the last station at the very southern areas is more than fifteen times greater than that of the first northern station. Tehran city is located in a semi-arid climate and experiences long hot summers. High rates of evapo-transpiration within urban green spaces and agricultural lands facilitate the salinization phenomenon in root zones. As a result, excess irrigation water eases the consequent percolation into aquifers. Furthermore, saline water intrusion from salt marshes located down south of the city is an expected consequence of wells overpumping. Such case is especially remarkable in hot seasons when an increased urban water demand is observed. Remarkable sulfate concentrations in saline water are mainly justified by percolation of sulfate containing fertilizers which are broadly used by local farmers in an uncontrolled manner. Surface run-offs and municipal
\end{abstract}

T. Nasrabadi $(\bowtie)$

Graduate Faculty of Environment, University of Tehran, \#23, Azin Avenue, Ghods Street, Enghelab Square, zip code: 1417853111 Tehran, Iran

e-mail: tnasrabadi@ut.ac.ir

P. Abbasi Maedeh

Civil-Environmental Engineering, University of Tehran, \#23, Azin Avenue, Ghods Street, Enghelab Square, zip code: 1417853111 Tehran, Iran wastewater leakage may also trigger the salinization process.

Keywords Intrusion - Irrigation - Salinity - Tehran city · Urban groundwater

\section{Introduction}

Water supply in metropolitan cities has been a major concern especially in recent decades (Parkinson and Tayler 2003; Navarro and Carbonell 2007). Different sources have been utilized for such ever increasing demand among which groundwater is proved to be the most reliable one (Howard et al. 2003). Its stable quality, abundance and reasonable exploitation costs are considered as the main advantages of this water source in comparison with other ones (Bauser et al. 2012). In developing countries where remarkable operation and maintenance costs of water treatment plants are not easily affordable, groundwater is the preferred alternative for water supply. The logic is reasonable while it requires no sophisticated treatment process. Furthermore, uncontrolled rapid urbanization accompanied by expansion of suburbs in mentioned regions, make groundwater the most accessible water supply source (Edmunds et al. 2002). Accordingly, major health threats may be exposed to inhabitants by groundwater contamination. This contamination may be due to urban storm water infiltration, irrigation of green spaces, industrial activities and the uncontrolled leakage of wastewater and septic tanks (Robertson et al. 1991; Jeong 2001; Rivett et al. 2002; Dechesne et al. 2004). The aquifers beneath urban areas may become polluted by toxic metals, organic compounds and major anions/cations. Each of mentioned pollutants 
has the potential to deteriorate the water supply and the environment (Vidal et al. 2000).

Groundwater quality degradation has become a serious environmental concern in Asian sprawling metropolises undergoing economic growth (Foster and Chilton 2004; Hosono et al. 2010). Groundwater salinization due to overpumping, excess irrigation, fertilizer leaching and nitrate pollution from wastewater leakage due to insufficient sewer systems are the major problems reported for these areas (Mukherjee et al. 2006; Umezawa et al. 2009). However, few studies have discussed detailed spatial distribution of above-mentioned hazards within the groundwater beneath Tehran city, Iran.

Tehran city is located between the latitudes of $35^{\circ}$ and $36^{\circ}$ north and the longitudes of $50^{\circ}$ and $53^{\circ}$ east. According to the latest national census, Tehran is considered as the most populated province within Iran. Being the capital of Tehran province, Tehran city with an approximate population of more than ten million people is a remarkable case among Middle East metropolitan cities (Nasrabadi et al. 2008). As the eighteenth most populated capital in the world, Tehran has undergone an enormous sprawl during recent decades (Asadpour and Nasrabadi 2011). Around 15 percent of Iran's total population lives in Tehran city which occupies less than 0.5 percent of the whole country's surface area. Such phenomenon has been accompanied by enhanced anthropogenic contamination load to surrounding environment including water bodies.

Geographically, Tehran city demonstrates a specific situation. Having an elevation of around 2,000 m, northern regions of the city are connected to mountainsides of the Alborz. The elevation shows a stable decreasing pattern southwards and drops to around $1,100 \mathrm{~m}$ in southern areas where the outskirts approach the margins of Kavir desert. Such topographical pattern dictates a similar groundwater flow and also contaminants transport direction.

The main sources of drinking water in Tehran city are Karadj River in the northwest, Jajrood River in the northeast, and more than 400 wells scattered mostly on the southern parts of the city (Pardakhti et al. 2011).

Five active water treatment plants-Minicity, Jalalieh, Kan, Hakimieh 3 and Hakimieh 4-are located in northern and central parts of the city. They process the surface water allocated to northern and central districts while water exploited from groundwater resource in southern areas does not go through any sophisticated treatment process. It is just chlorinated before being pumped into the distribution network.

According to the data acquired from Tehran water and wastewater firm, the total volume of annual urban consumed water is estimated to be more than one billion cubic meters. Around sixty percent of the whole volume is provided through surface water resources, while the rest forty percent is withdrawn from wells mostly dug in southern areas.

Regional geology

Northern region of Tehran province is a part of Alborz Mountains while southern Tehran areas are located in central Iran plain like low lands. According to the National Geosciences Database of Iran, geomorphologic and geological characteristics of this province are closely related to geographic features of it. Northern parts of Tehran is a portion of a southward curved mountain range, therefore has mountain like morphology. Tehran plain generally has a plain like physiographic feature in which hilly land structure forms a rough morphology such as southeastern Tehran heights, southern Karadj hills and southern Kahrizak hilly lands. It is believed that Tehran province belongs to Alborz and central Iran structural zones. The boundary between these zones matches on northern Tehran thrust fault. Alborz heights have thrusted on Tehran plain due to this fault.

The oldest stratigraphic units of Tehran province include a late Precambrian to mid Triassic platform sequence. Such units emprise several geologic formations and sedimentary unconformities indicating land-forming movements during late Precambrian to mid Triassic time. Upper Triassic to mid Jurassic sequences of Tehran province is formed of coal-bearing shale and sandstone (Shemshak formation). Coal layers can be found especially in northern margin of Tehran. Mid Jurassic cretaceous marl and carbonate complexes are marine tectonostratigraphic unit with mountain forming feature in most parts of province.

In southern half of Tehran province, against northern half, Neogene units has a wide spreading formed mainly of marl, red sandstones and conglomerates with red hilly land feature. In Tehran province, several epeirogenic and orogenic events resulted in present morphotectonic of province. Geological structure (e.g., faults and folds) have NW$\mathrm{SE}$ general trend in western parts turning to NE trend at east.

\section{Materials and methods}

In order to appropriately cover the study area, nine boreholes were selected for groundwater sampling. Spatial characteristics of the stations are shown in Table 1.

The location of Tehran city in Iran and the layout of groundwater sampling stations within the city are demonstrated in Fig. 1.

The groundwater depth in all nine sampling stations is presented in Fig. 2. As it is seen the overall groundwater flow direction is southwards. 
Table 1 UTM coordinates of sampling stations within the study area

\begin{tabular}{lll}
\hline Sampling station & \multicolumn{2}{l}{ UTM coordinates } \\
\cline { 2 - 3 } & $X$ & $Y$ \\
\hline S1 & 527,850 & $3,957,050$ \\
S2 & 528,850 & $3,951,000$ \\
S3 & 532,150 & $3,953,350$ \\
S4 & 532,750 & $3,946,350$ \\
S5 & 536,625 & $3,929,500$ \\
S6 & 532,300 & $3,927,975$ \\
S7 & 536,625 & $3,923,500$ \\
S8 & 533,250 & $3,909,750$ \\
S9 & 542,300 & $3,905,050$ \\
\hline
\end{tabular}

BAT Groundwater Sampler-Envirosampler ${ }^{\circledR}$ was used for groundwater sampling. Samples were collected in polyethylene bottles for analysis of electrical conductivity (EC), $\mathrm{pH}$, major anions (carbonate, bicarbonate, chloride and sulfate) and cations (calcium, magnesium, sodium and potassium). Electrical conductivity and $\mathrm{pH}$ were measured in situ using Hanna Combo pH/EC/tester Model HI98129 low range. Being filtered through polycarbonate filters $(0.45 \mathrm{~mm}$ pore size $)$, samples were divided into two 500-cc-polyethylene containers and the ones for cations analysis were acidified by concentrated $\mathrm{HNO}_{3}$. Calcium, potassium and sodium were measured by flame photometry, while magnesium was determined by the flame atomic absorption spectrometer (Baghvand et al. 2010). Regarding anions, bicarbonate and carbonate were measured through titration (method number 4500), while sulfate and chloride were analyzed by direct spectrophotometer reading (method number 8051 by HACH DR/2000) and argentometric process (method number 2330), respectively. Data processing was performed by software like AQQA and SPSS 11.

\section{Results and discussion}

Groundwater samples were collected in summer 2012. Hydrochemical characteristics of groundwater samples are demonstrated in Table 2. $\mathrm{pH}$ values do not show a meaningful change among nine groundwater samples. Such behavior pattern is in accordance with that of carbonate/ bicarbonate ions. Electrical conductivity values change from $462 \mu \mathrm{S} / \mathrm{cm}$ in the second station (S2) to $7,160 \mu \mathrm{S} / \mathrm{cm}$ in the ninth one (S9). Potassium concentration seems to experience no change among the first seven stations ( $\mathrm{S} 1-$ S7) of the studied aquifer, although the last two stations (S8 and S9) show remarkably higher concentrations in comparison with others. Concentration of other major anions and cations including sodium, calcium, magnesium, sulfate and chloride obey an ascending trend southwards, although the increasing rate of $\mathrm{Na}^{+}, \mathrm{SO}_{4}{ }^{2-}$ and $\mathrm{Cl}^{-}$concentrations is sharper than that of $\mathrm{Ca}^{2+}$ and $\mathrm{Mg}^{2+}$.
Fig. 1 Demonstration of Tehran city in Iran and the layout of groundwater sampling stations

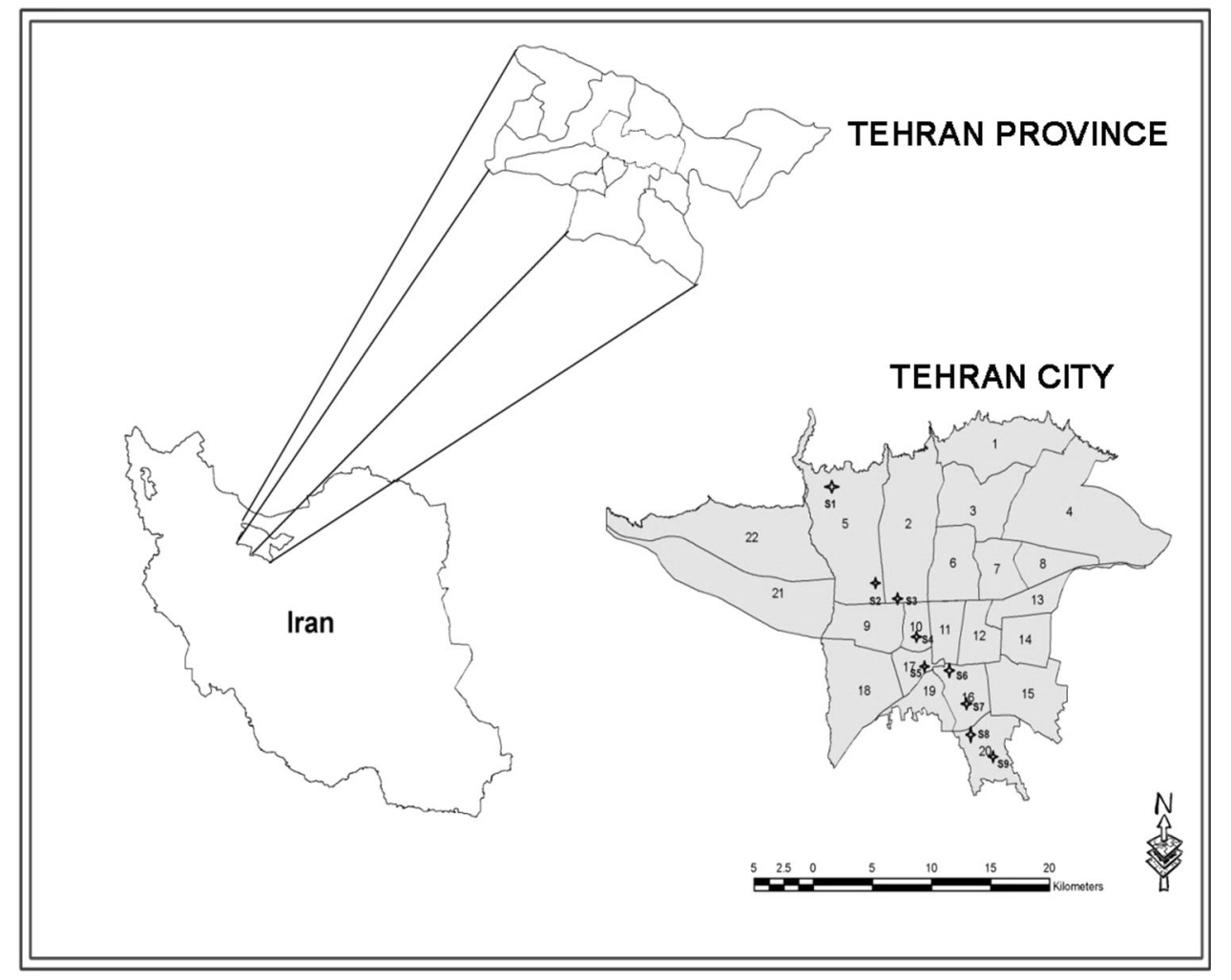


Fig. 2 Groundwater depth in nine sampling stations

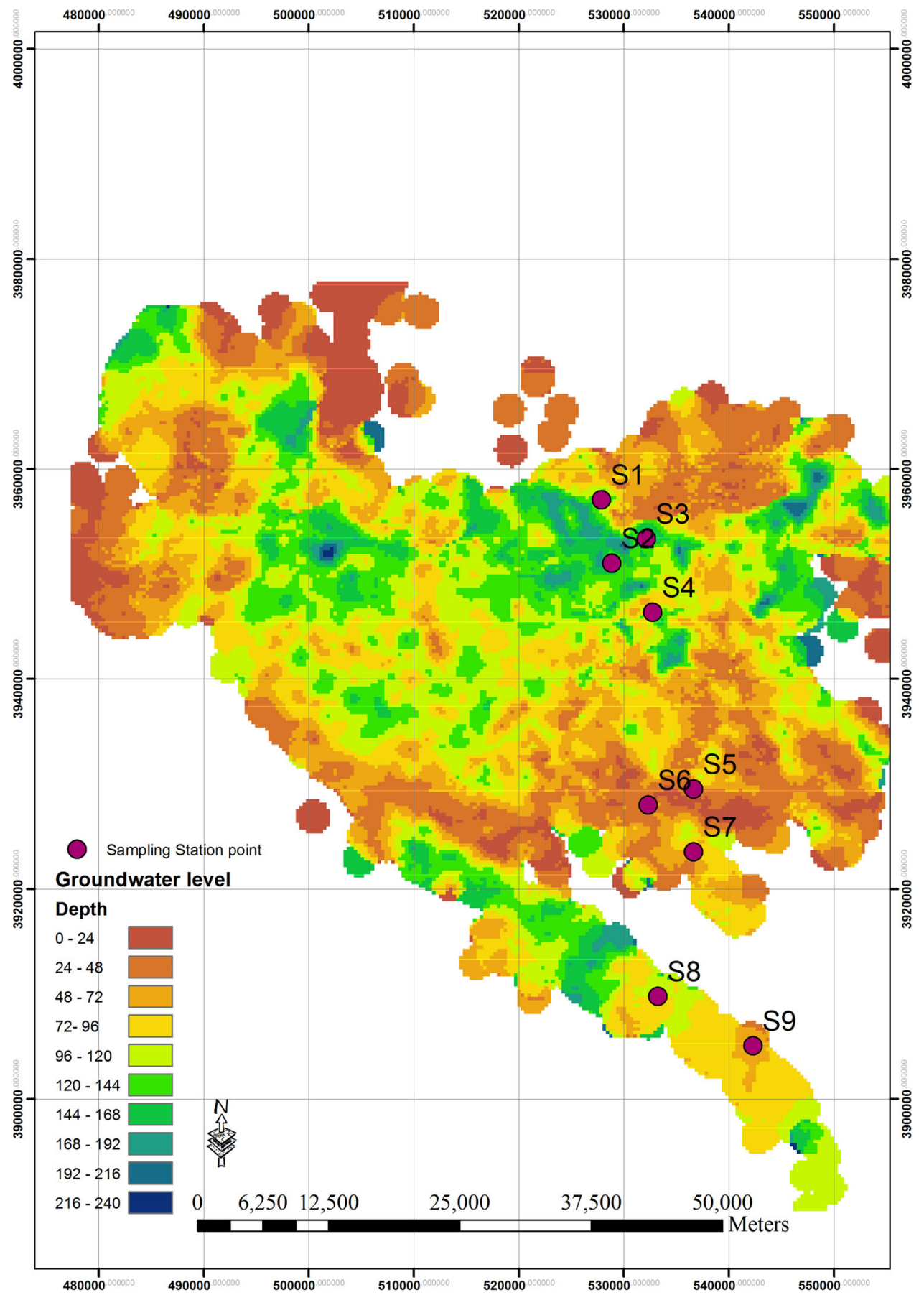

Some descriptive statistics of measured parameters monitored in groundwater samples are indicated in Table 3. Regarding standard deviation and coefficient of variation $(\mathrm{CV})$ values, a moderate to high variability in concentration of major anions and cations is observed within the study area. Parameters sulfate, potassium, sodium and chloride indicate the most remarkable spatial variation in the studied aquifer (Table 3 ).

Box and whiskers plots are also considered to evaluate the intensity of variation of different ions concentration. The most elongated inter-quartile ranges belong to sodium, chloride and sulfate. Furthermore, a distinct difference is observed between median and maximum values of three above-mentioned ions (Fig. 3). Such pattern may be considered as an evidence of local contamination input to the aquifer.

In order to distinguish the behavior similarity of different stations, cluster analysis was taken into consideration. Cluster analysis has been widely used to group cases or alternatives in similar studies (Kuppusamy and Giridhar 2006; Karbassi et al. 2007; Shrestha and Kazama 2007; 
Table 2 Chemical analysis of groundwater samples

\begin{tabular}{|c|c|c|c|c|c|c|c|c|c|c|c|c|}
\hline \multirow[t]{2}{*}{ Station } & \multirow[t]{2}{*}{$\mathrm{pH}$} & \multirow[t]{2}{*}{$\mathrm{EC}(\mu \mathrm{S} / \mathrm{cm})$} & \multicolumn{4}{|c|}{ Cations (meq/L) } & \multicolumn{3}{|c|}{ Anions (meq/L) } & \multirow[t]{2}{*}{ SAR } & \multirow[t]{2}{*}{$\sum$ Cations } & \multirow{2}{*}{$\sum$ Anions } \\
\hline & & & $\mathrm{K}^{+}$ & $\mathrm{Na}^{+}$ & $\mathrm{Ca}^{2+}$ & $\mathrm{Mg}^{2+}$ & $\mathrm{SO}_{4}{ }^{2-}$ & $\mathrm{Cl}^{-}$ & $\mathrm{HCO}_{3}{ }^{-}$ & & & \\
\hline S1 & 7.2 & 768 & 0.02 & 1.5 & 3.81 & 1.62 & 1.7 & 2.7 & 2.21 & 0.91 & 6.9 & 6.6 \\
\hline $\mathrm{S} 2$ & 7.4 & 472 & 0.01 & 3.09 & 2.23 & 0.27 & 1.13 & 1.6 & 2.31 & 2.76 & 5.6 & 5.5 \\
\hline S3 & 7.7 & 1,020 & 0.02 & 2.55 & 6 & 1.8 & 1.6 & 4.6 & 3.8 & 1.29 & 10.4 & 10.7 \\
\hline S4 & 7.9 & 1,472 & 0.03 & 4.4 & 6.9 & 3.55 & 2.35 & 4.9 & 6.75 & 1.93 & 14.9 & 15.9 \\
\hline S5 & 7.3 & 3,380 & 0.01 & 16 & 8.68 & 9.39 & 10.03 & 15.1 & 9.12 & 5.32 & 34.1 & 35.3 \\
\hline S6 & 7.6 & 2,910 & 0.05 & 19 & 7.16 & 8 & 16 & 12 & 7.48 & 6.9 & 34.2 & 36.2 \\
\hline S7 & 7.9 & 3,630 & 0.04 & 18 & 10.2 & 7.9 & 12.8 & 15.2 & 8 & 5.98 & 36.1 & 36.3 \\
\hline S8 & 7.6 & 5,000 & 0.11 & 29 & 12.6 & 11.2 & 18.37 & 27.9 & 5.95 & 8.41 & 52.9 & 52.4 \\
\hline S9 & 7.8 & 7,160 & 0.11 & 45 & 19.2 & 12 & 41.25 & 28 & 6.47 & 11.39 & 76.3 & 76.2 \\
\hline
\end{tabular}

SAR Sodium absorption ratio

Table 3 Descriptive statistics of chemical composition of groundwater in Tehran city $(N=9)$

\begin{tabular}{|c|c|c|c|c|c|c|}
\hline Parameter & Minimum & Maximum & Mean & Std. deviation & $\mathrm{CV} \%$ & Skewness \\
\hline $\mathrm{pH}$ & 7.22 & 8.00 & 7.64 & 0.28 & 3.66 & -0.184 \\
\hline $\mathrm{EC}(\mu \mathrm{S} / \mathrm{cm})$ & 472.00 & $7,160.00$ & $2,868.00$ & $2,217.15$ & 77.31 & 0.845 \\
\hline $\mathrm{K}^{+}(\mathrm{meq} / \mathrm{L})$ & 0.01 & 0.11 & 0.04 & 0.04 & 100.00 & 1.181 \\
\hline $\mathrm{Na}^{+}(\mathrm{meq} / \mathrm{L})$ & 1.50 & 45.00 & 15.39 & 14.63 & 95.06 & 1.055 \\
\hline $\mathrm{Ca}^{2+}(\mathrm{meq} / \mathrm{L})$ & 2.23 & 19.20 & 8.53 & 5.08 & 59.55 & 1.116 \\
\hline $\mathrm{Mg}^{2+}(\mathrm{meq} / \mathrm{L})$ & 0.27 & 12.00 & 6.19 & 4.44 & 71.73 & -0.076 \\
\hline $\mathrm{SO}_{4}{ }^{2-}(\mathrm{meq} / \mathrm{L})$ & 1.13 & 41.25 & 11.69 & 12.95 & 110.78 & 1.642 \\
\hline $\mathrm{Cl}^{-}(\mathrm{meq} / \mathrm{L})$ & 1.60 & 28.00 & 12.44 & 10.17 & 81.75 & 0.671 \\
\hline $\mathrm{HCO}_{3}{ }^{-}$(meq/L) & 2.21 & 9.12 & 5.79 & 2.48 & 42.83 & -0.442 \\
\hline SAR & 0.91 & 11.39 & 4.99 & 3.57 & 71.54 & 0.538 \\
\hline
\end{tabular}

$C V$ Coefficient of variation

Nasrabadi et al. 2010). Variables, cases and the interval were determined as concentration of major anions and cations, sampling stations and squared Euclidean distance, respectively. To prevent biased interpretations, $Z$ scores of concentration values were used for data process. The stations are categorized in two distinct clusters (Fig. 4). Being gathered in cluster A, stations 1-4 located in northern parts of the city show a similar behavior regarding the concentration of major anions and cations. On the other hand, cluster B including stations 5-9 indicates such similarity among southern stations. In a more detailed analysis, stations 8 and 9 in cluster $\mathrm{B}$ may also be considered as a separate subgroup highlighting a slight change in the very southern parts of the study area.

Classifying the whole sampling stations into two distinct groups is also confirmed by series plot showing the major ions concentration (Fig. 5). In accordance with the results achieved by cluster analysis, the referenced ions concentration in the first four stations (cluster A) is remarkably lower than that of the last five ones (cluster B).

Piper diagram was used to show the dispersion of dominant anions $\left(\mathrm{HCO}_{3}{ }^{-}, \mathrm{Cl}^{-}\right.$and $\left.\mathrm{SO}_{4}{ }^{2-}\right)$ and cations $\left(\mathrm{Ca}^{2+}, \mathrm{Mg}^{2+}\right.$ and $\left.\mathrm{K}^{+}+\mathrm{Na}^{+}\right)$in groundwater samples. Lithological heterogeneities along with anthropogenic pollution sources may be addressed as the main factors determining the dominant hydrochemical compounds in aquifers (Jiang et al. 2009). Rather than one unique distinguished dominant type, a variety of types is observed in different stations. The dominant types vary from $\mathrm{Ca}+$ $\mathrm{Mg}-\mathrm{HCO}_{3}$ in northern stations to $\mathrm{Na}+\mathrm{K}-\mathrm{Cl}+\mathrm{SO}_{4}$ in very southern ones (Fig. 6). Such hydrogeochemical pattern may be created by water-rock interaction as well as anthropogenic intervention.

Drinking would be the first and most important use considered for an aquifer beneath a metropolis like 


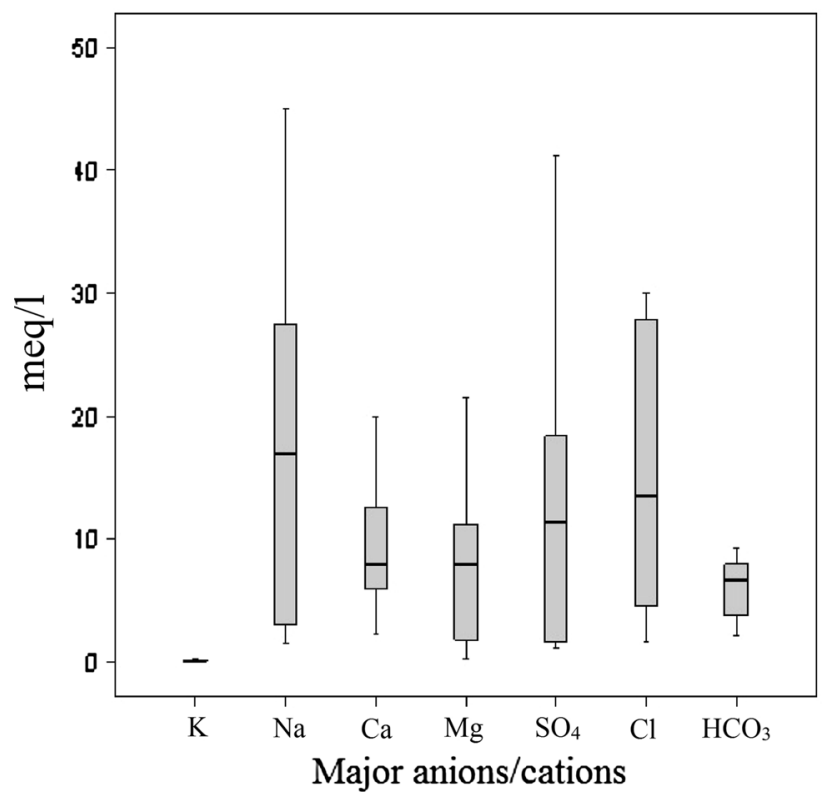

Fig. 3 Box and whiskers plots of major ions in Tehran city groundwater
Tehran city. To evaluate the drinking suitability of sampled groundwaters, Schoeller's diagram is plotted (Fig. 7). According to the diagram classification ladder, good, acceptable, not suitable and bad quality levels are assessed for stations $1-3,4,5-7$ and $8-$, respectively. As it is concluded from the diagram, more than a half of total samples is not regarded as suitable for drinking.

To irrigate the urban green spaces within the city and agricultural lands on the outskirts, the groundwater should meet the required standards. Electrical conductivity (EC) and sodium absorption ratio (SAR) are the most significant parameters considered for evaluating a water type suitability for agricultural uses. EC and SAR are referred as precursors of salinity and sodium alkali hazards, respectively. Regarding salinity hazard, stations $1-4$ show medium- to high-risk levels, while for stations 5-9 the risk status is determined as very high. On the other hand, sodium alkali threat is appeared to be low for stations 1-4, medium for stations 4-7 and very high for the last two stations (Fig. 8).
Fig. 4 Dendrogram showing the stations similarity due to major anions and cations concentration

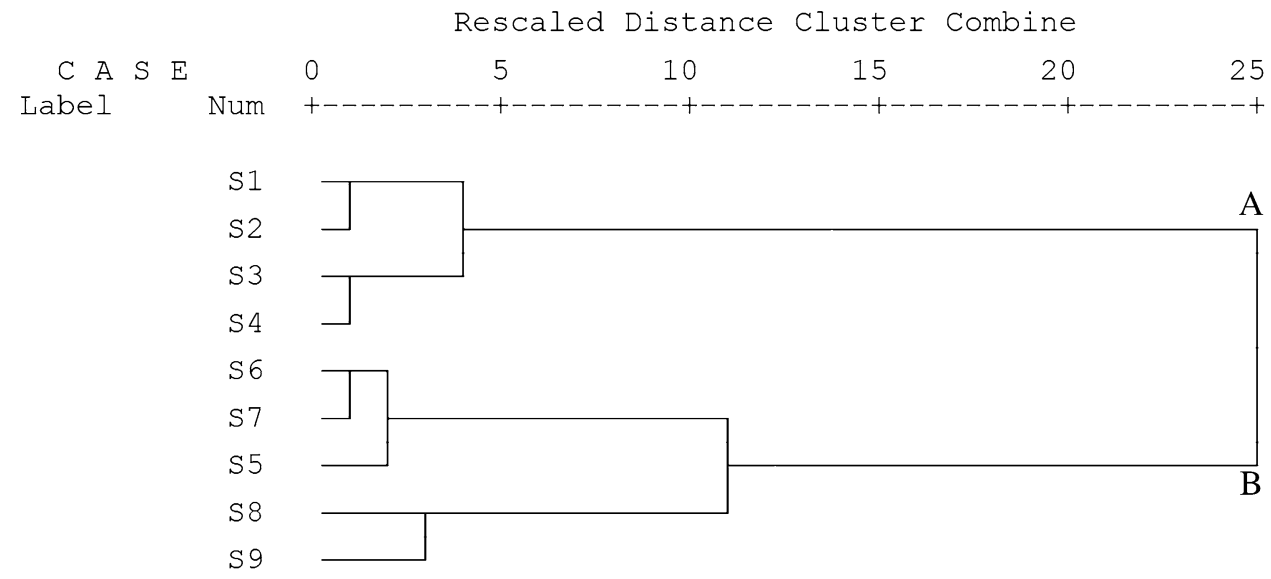

Fig. 5 Distribution pattern of major anions and cations concentration among sampling stations

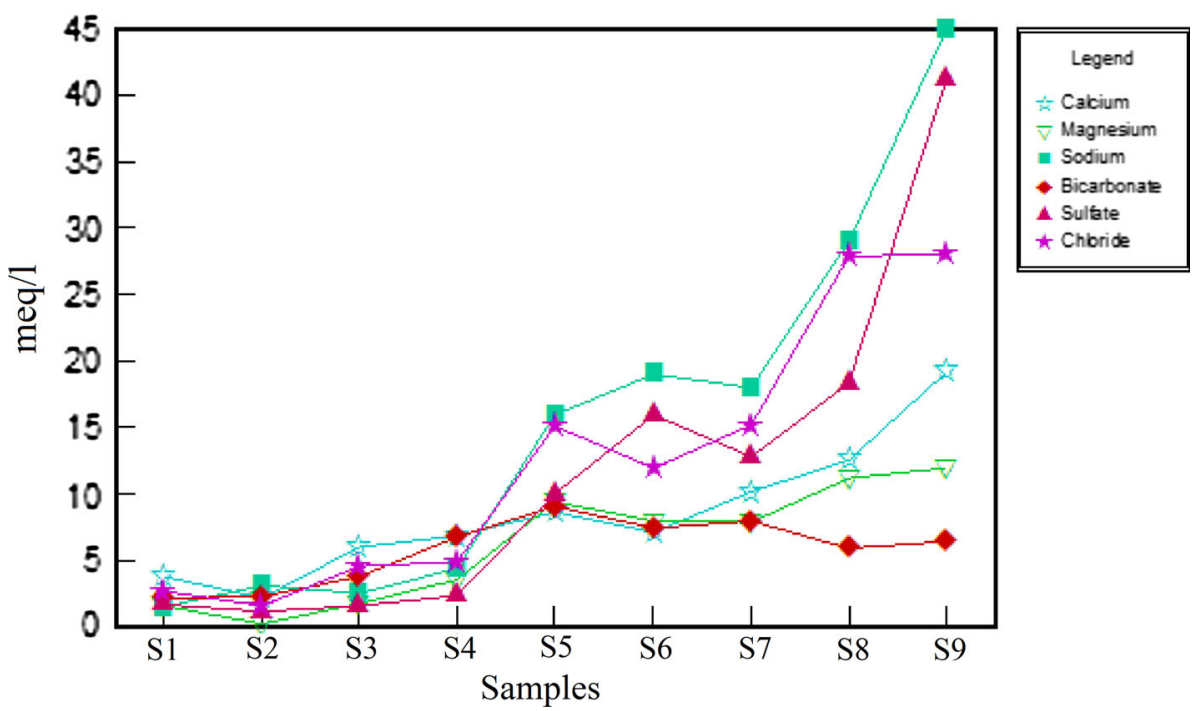




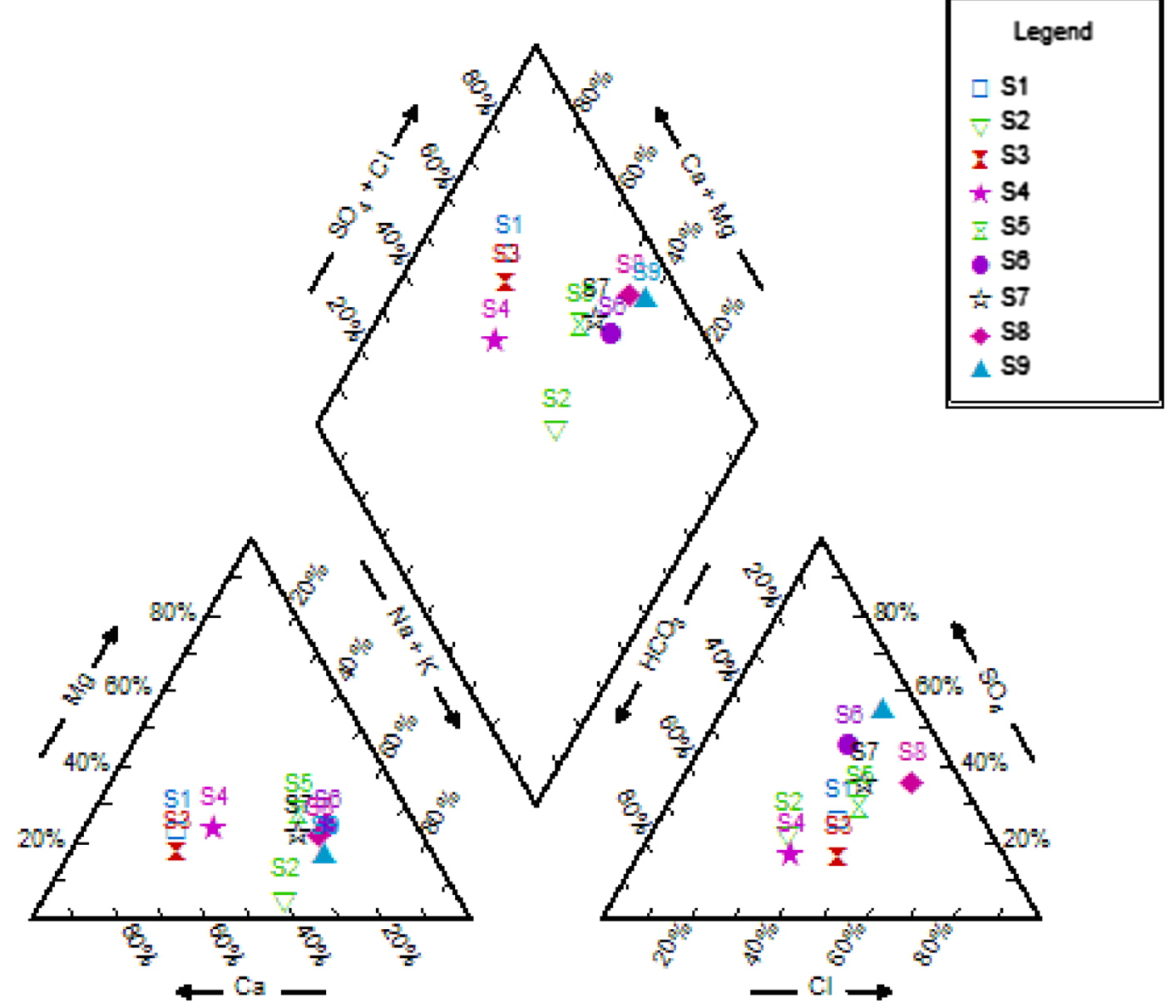

Fig. 6 Piper diagram showing the dominant water type within the study area

Fig. 7 Schoeller diagram showing groundwater suitability for drinking use

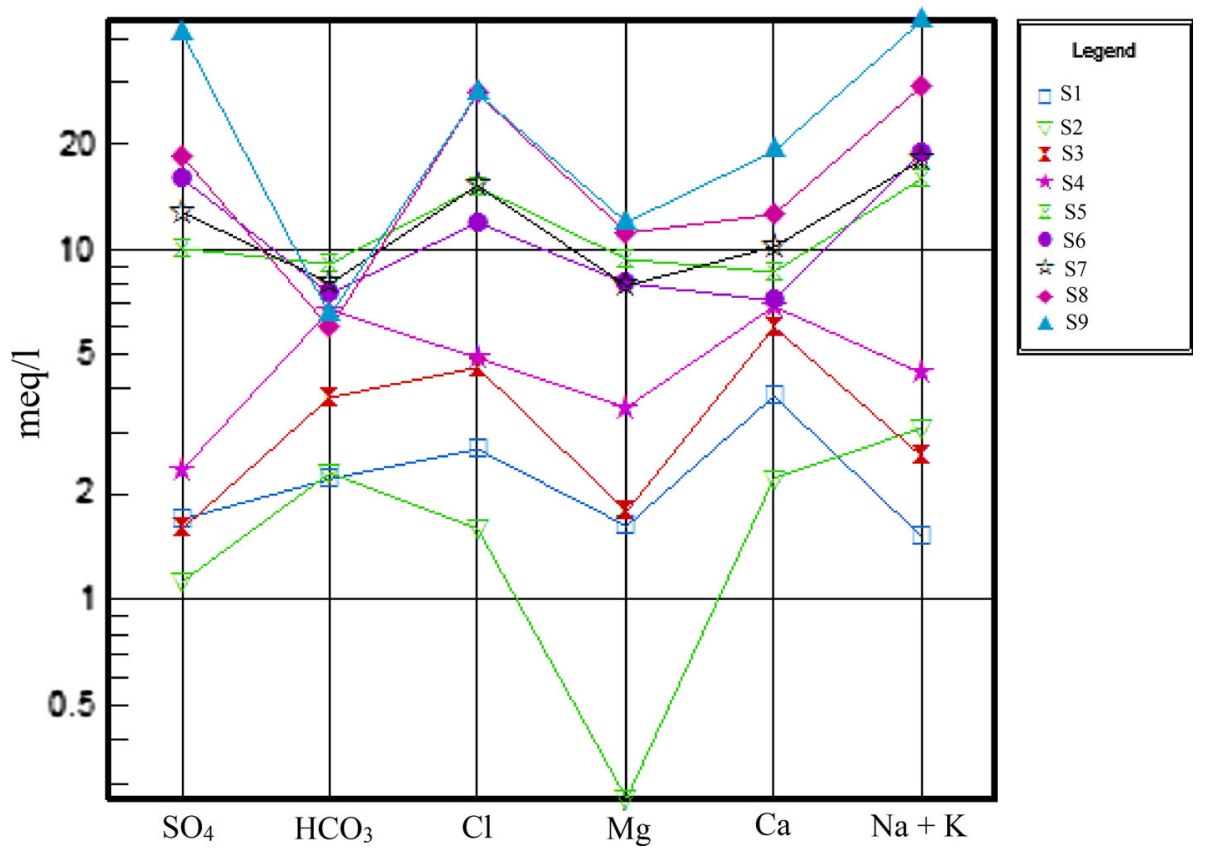


Fig. 8 Wilcox diagram indicating groundwater suitability for agricultural use

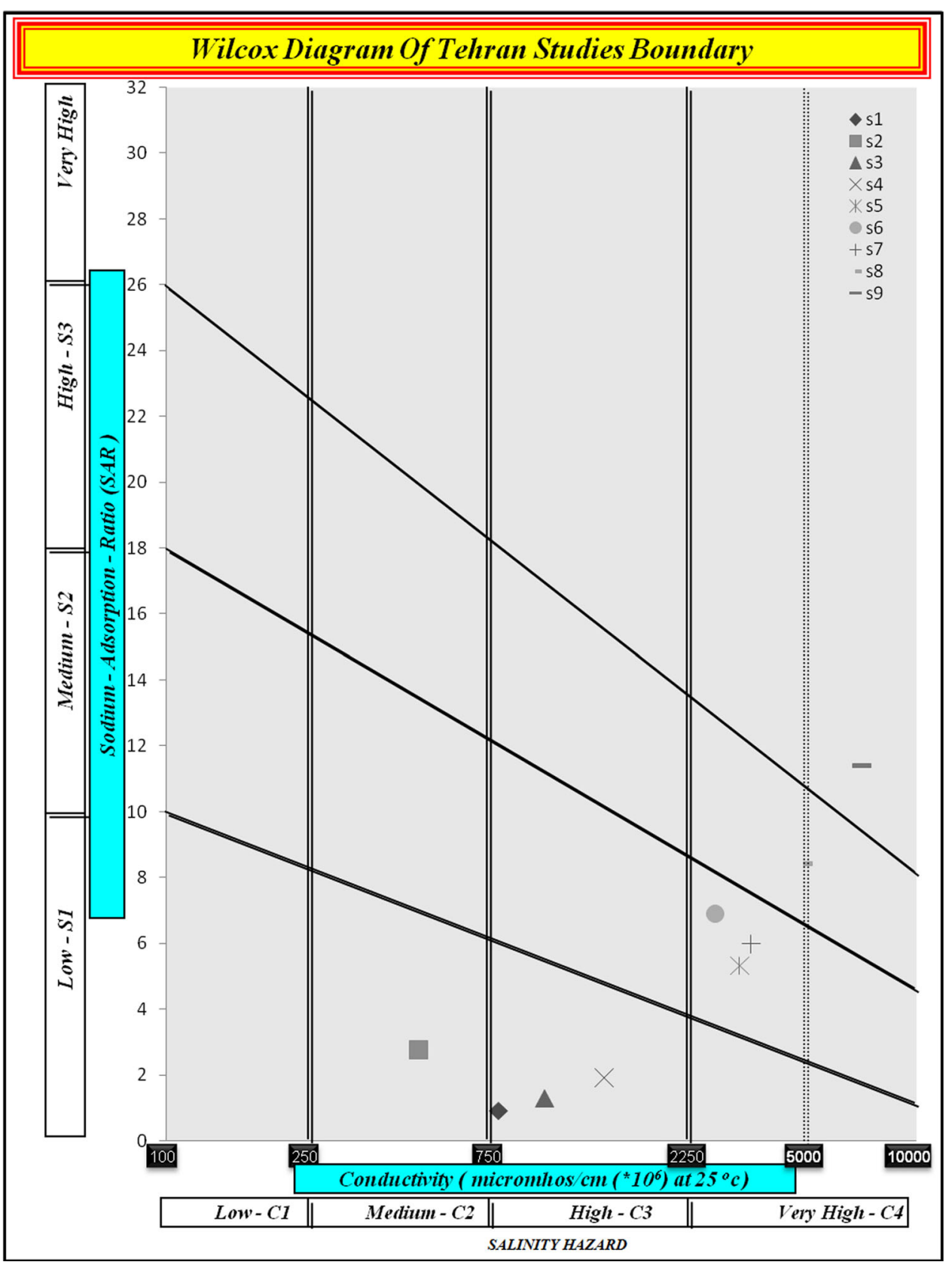

\section{Conclusion}

Groundwater quality with an emphasis on major anions and cations is considered in an aquifer beneath Tehran city, a metropolis in southwestern Asia. Nine sampling stations were selected from most elevated northern areas to the lowest southern ones. Composite sampling campaign was performed in summer 2012, and parameters $\mathrm{Na}^{+}, \mathrm{K}^{+}$, $\mathrm{Ca}^{2+}, \mathrm{Mg}^{2+}, \mathrm{Cl}^{-}, \mathrm{SO}_{4}{ }^{2-}, \mathrm{HCO}_{3}{ }^{-}, \mathrm{CO}_{3}{ }^{2-}, \mathrm{EC}$ and $\mathrm{pH}$ were measured. The whole nine stations were classified into two distinct clusters according to their behavior similarity regarding major anions and cations concentration. The first four groundwater samples from northern parts of the city (cluster A) appeared to have acceptable characteristics for agricultural and drinking uses while the last five ones (cluster B) do not meet the required guidelines for mentioned uses.

Generally, calcium, magnesium and bicarbonate ions show higher concentrations in the groundwater samples collected from northern stations in comparison with those collected from southern ones. Such pattern suggests that the human intervention in mentioned areas is minimal and the geopogenic source (water-rock interaction) plays the key role in determining the dominant water type. On the 
contrary, chloride, sulfate and sodium ions concentration appeared to be relatively higher in southern stations. The dominance of mentioned ions is more emphasized in last two stations (S8 and S9). This manipulated distribution pattern may be regarded as a result of human interference that has aversely affected the aquifer quality.

An intensified agricultural land use is observed in southern outskirts which plays a key role in supplying the citizens' demand. Being adjacent to the southern frontiers of the sprawling Tehran city, the farms are located on the northern margins of Kavir desert salt marshes as well. Such layout facilitates the saline water intrusion from southern salt marshes into the aquifer especially in hot seasons when more urban water demand is expected. Tehran city is located in a semi-arid climate and experiences long hot summers. High rates of evapo-transpiration within urban green spaces and agricultural lands facilitate the salinization phenomenon, and excess irrigation water eases the consequent percolation into aquifers. Similar justifications have been reported as the main reason of groundwater salinization in arid and semi-arid urban areas (Rodvang and Simpkins 2001; Oren et al. 2004; Jiang et al. 2009). Climatic conditions have the potential to adversely affect the groundwater quality from another point of view. The main rivers supplying Tehran city water demand have their lowest flow rate in hot seasons, and such decrease regime has become more intensified during recent years. Such deficiency in supplying the city water demand should be compensated by groundwater resources as the sole other alternative. Accordingly, saline water intrusion is assumed to be an expected consequence of wells overpumping especially in southern areas where a higher density of wells is observed. The intruded saline water contains remarkable concentrations of $\mathrm{Na}^{+}, \mathrm{Cl}^{-}$and $\mathrm{SO}_{4}{ }^{2-}$. Abnormally highsulfate concentrations in saline water are justified by percolation of sulfate containing fertilizers (super phosphate and ammonium sulfate) which are mainly used by local farmers in an uncontrolled manner. Pyrite oxidation within adjacent limestone aquifers may also be regarded as a geopogenic source of such pollution. Isotopic studies need to be developed to identify the exact source of sulfate pollution through further research. Surface run-offs and municipal wastewater which penetrate the groundwater via leakage from insufficient sewer networks/septic tanks or through percolation from numerous wastewater sorptive wells also trigger the salinization process. Five hundred percent of urban population growth in comparison with 1960 (Asadpour and Nasrabadi 2011) may tragically manifest the human intervention in groundwater quality degradation of Tehran city.

Acknowledgments Authors want to appreciate the scientific support of Graduate Faculty of Environment, University of Tehran.

\section{References}

Asadpour GA, Nasrabadi T (2011) Municipal and medical solid waste management in different districts of Tehran, Iran. Fresenius Environ Bull 20(12):3241-3245

Baghvand A, Nasrabadi T, Nabi Bidhendi GR, Vosoogh A, Karbassi AR, Mehrdadi N (2010) Groundwater quality degradation of an aquifer in Iran central desert. Desalination 260:264-275

Bauser G, Franssen H, Stauffer F, Kaiser H, Kuhlmann U, Kinzelbach W (2012) A comparison study of two different control criteria for the real-time management of urban groundwater works. J Environ Manag 105:21-29

Dechesne M, Barraud S, Bardin JP (2004) Indicators for hydraulic pollution retention assessment of stormwater infiltration basins. J Environ Manag 71:371-380

Edmunds WM, Carrillo-Rivera JJ, Cardona A (2002) Geochemical evolution of groundwater beneath Mexico City. J Hydrol 258:1-24

Foster SSD, Chilton PJ (2004) Downstream of downtown: urban wastewater as groundwater recharge. Hydrogeol J 12:115-120

Hosono T, Siringan F, Yamanaka T, Umezawa Y, Onodera S, Nakano T, Taniguchi M (2010) Application of multi-isotope ratios to study the source and quality of urban groundwater in Metro Manila. Philipp Appl Geochem 25:900-909

Howard G, Pedley S, Barret M, Nalubega M, Johal K (2003) Risk factors contributing to microbiological contamination of shallow groundwater in Kampala, Uganda. Water Resour 37:3421-3429

Jeong CH (2001) Effect of land use and urbanization on hydrochemistry and contamination of groundwater from Taejon area, Korea. J Hydrol 253:194-210

Jiang Y, Wu Y, Groves C, Yuan D, Kambesis P (2009) Natural and anthropogenic factors affecting the groundwater quality in the Nandong karst underground river system in Yunan, China. J Contam Hydrol 109:49-61

Karbassi AR, Nouri J, Ayaz GO (2007) Flocculation of trace metals during mixing of Talar River water with Caspian Seawater. Int J Environ Res Winter 1(1):66-73

Kuppusamy MR, Giridhar VV (2006) Factor analysis of water quality characteristics including trace metal speciation in the coastal environmental system of Chennai Ennore. Environ Int 32:174-179

Mukherjee A, Sengupta MK, Hossain MA, Ahamed S, Das B, Nayak B, Lodh D, Rahman MM, Chakraborti D (2006) Arsenic contamination in groundwater: a global perspective with emphasis on Asian scenario. J Health Popul Nutr 24:142-163

Nasrabadi T, Hoveidi H, Nabi Bidhendi GR, Yavari AR, Mohammadnejad S (2008) Evaluating citizen attitudes and participation in solid waste management in Tehran, Iran. J Environ Health 71(5):30-33

Nasrabadi T, Nabi Bidhendi GR, Karbassi AR, Mehrdadi N (2010) Evaluating the efficiency of sediment metal pollution indices in interpreting the pollution of Haraz River sediments, southern Caspian Sea basin. Environ Monit Assess 171:395-410

Navarro A, Carbonell M (2007) Evaluation of groundwater contamination beneath an urban environment: the Beso's river basin (Barcelona, Spain). J Environ Manag 85:259-269

Oren O, Yechieli Y, Boehlke JK, Dody A (2004) Contamination of groundwater under cultivated fields in an arid environment, central Arava Valley, Israel. J Hydrol 290:312-328

Pardakhti AR, Nabi Bidhendi GR, Torabian A, Karbassi AR, Yunesian M (2011) Comparative cancer risk assessment of THMs in drinking water from well water sources and surface water sources. Environ Monit Assess 179:499-507

Parkinson J, Tayler K (2003) Decentralized wastewater management in periurban areas in low-income countries. Environ Urban 15(1):75-89 
Rivett MO, Petts J, Butler B, Martin I (2002) Remediation of contaminated land and groundwater: experience in England and Wales. J Environ Manag 65:251-268

Robertson WD, Cherry JA, Sudicky EA (1991) Groundwater contamination from two small septic systems on sand aquifers. Ground Water 29(1):82-92

Rodvang SJ, Simpkins WW (2001) Agricultural contaminants in quaternary aquitards: a review of occurrence and fate in North America. Hydrogeol J 9:44-59

Shrestha S, Kazama F (2007) Assessment of surface water quality using multivariate statistical techniques: a case study of the Fuji river basin, Japan. Environ Model Softw 22:464-475
Umezawa Y, Hosono T, Onodera S, Siringan F, Buapeng S, Delinom R, Yoshimizu C, Tayasu I, Nagata T, Taniguchi M (2009) Tracing the sources of nitrate and ammonium contaminations in groundwater at developing Asian megacities, using GIS data and nitrate d15N and d180. Sci Total Environ 407:3219-3231

Vidal M, Melgar J, López A, Santoalla MC (2000) Spatial and temporal hydrochemical changes in groundwater under the contaminating effects of fertilizers and wastewater. J Environ Manag 60:215-225 